\title{
KENYAMANAN TERMAL KLIMATOLOGIS KOTA-KOTA BESAR DI PULAU SULAWESI BERDASARKAN TEMPERATURE HUMIDITY INDEX (THI)
}

\author{
Femmy Marsitha B1 1,a) Wendel Jan Pattipeilohy ${ }^{2, b)}$, Rista Hernandi Virgianto ${ }^{3, c)}$ \\ ${ }^{1}$ Pusat Informasi Perubahan Iklim, BMKG \\ ${ }^{2}$ Stasiun Klimatologi Manokwari Selatan, BMKG \\ ${ }^{3}$ Program Studi Diploma IV Klimatologi, STMKG \\ Email: ${ }^{a}$ femmymarsitha@gmail.com
}

\begin{abstract}
Increased urbanization and reduced green-open-space in urban areas cause urban warming problems knows as Urban Heat Island (UHI) which have implications for the level of thermal comfort that urban residents can feel outdoors. This study examines thermal comfort climatology levels and their trends in large cities in Sulawesi based on the THI index. Two climate variables are used to calculate the THI index, they are average daily air temperature and relative daily humidity for 1985-2012 period at 6 observation points representing each city. The THI formula used is a formula with a modified comfort limit for a tropical climate. Climatological analysis shows that Palu and Maтuju are cities with relatively low moisture content and relatively high climatological temperatures compared to other cities. Thus, the two cities have the lowest level of comfort felt by the urban population of $10.2 \%$ and $24.7 \%$, while Manado and North Minahasa are the most comfortable cities with a percentage of $31.6 \%$ and $31.9 \%$. The THI index tends to increase except in Mamuju city with the largest rate experienced by the city of Makassar at $0.03{ }^{\circ} \mathrm{C} \mathrm{per}$ year or $0.3{ }^{\circ} \mathrm{C}$ per 10 years with a coefficient of determination of $41.6 \%$.
\end{abstract}

Keywords : thermal comfort level, humidity temperature index, urban heat island, Sulawesi

\begin{abstract}
Abstrak
Meningkatnya urbanisasi dan berkurangnya ruang terbuka hijau di wilayah perkotaan menyebabkan permasalahan pemanasan perkotaan, yaitu fenomena Urban Heat Island (UHI) yang akan berimplikasi kepada tingkat kenyamanan termal yang dapat dirasakan penduduk urban di luar ruangan. Penelitian ini mengkaji tingkat kenyamanan termal secara klimatologis serta kecenderungannya di kota-kota besar di Pulau Sulawesi dengan menggunakan indeks THI. Dua variabel iklim digunakan untuk menghitung indeks THI, yaitu suhu udara rata-rata harian dan kelembapan relatif harian selama periode 1985-2012 di 6 titik pengamatan yang mewakili masing-masing kota. Formula THI yang digunakan adalah formula dengan batas kenyamanan yang telah dimodifikasi untuk iklim tropis. Analisis klimatologis menunjukkan Palu dan Mamuju merupakan kota dengan kandungan uap air yang relatif rendah dengan suhu yang relatif tinggi secara klimatologis jika dibandingkan dengan kota lainnya. Sehingga, kedua kota tersebut memiliki tingkat kenyamanan yang paling rendah dirasakan oleh populasi perkotaan secara berturut yaitu 10,2\% dan 24,7\%, sedangkan Manado dan Minahasa Utara merupakan kota yang paling nyaman dengan prosentase, yaitu 31,6 \% dan 31,9\%. Indeks THI tersebut cenderung mengalami peningkatan kecuali di Mamuju dengan laju terbesar dialami oleh Makassar sebesar $0,03{ }^{\circ} \mathrm{C}$ per tahun atau $0,3{ }^{\circ} \mathrm{C}$ per 10 tahun dengan koefisien determinasi sebesar $41,6 \%$.
\end{abstract}

Kata Kunci : tingkat kenyamanan termal, temperature humidity index, urban heat island, Sulawesi

\section{PENDAHULUAN}

Urbanisasi dan peningkatan populasi berdampak pada peningkatan kegiatan antropogenik seperti pertumbuhan berbagai industri untuk memenuhi kebutuhan rumah tangga di area perkotaan dan pedesaan. Situasi ini dapat memberikan kerugian sosial terutama dalam aspek kenyamanan termal, kesehatan dan konsumsi energi (Tursilowati, 2005; Maru dan Ahmad, 2014). Selain itu, peningkatan urbanisasi yang cepat tanpa diikuti oleh keseimbangan lingkungan dapat menyebabkan permasalahan pemanasan perkotaan salah satunya adalah fenomena Urban Heat Island (UHI). Selain karena peningkatan emisi CO2 (Rushayati dan Hermawan, 2013; Wati dan Fatkhuroyan, 2017), faktor yang berkontribusi terhadap UHI yaitu berkurangnya Ruang Terbuka Hijau (RTH), peningkatan kendaraan bermotor dan perluasan wilayah perkotaan (Effendy, 2007; Wati dan Fatkhuroyan, 2017). Hal ini dibuktikan bahwa terjadi peningkatan suhu udara pada wilayah yang mengalami penurunan RTH. 
Kalfuadi (2009) menyebutkan apabila penutup lahan bervegetasi dan badan air dikonversi menjadi daerah non vegetasi seperti pemukiman akan menyebabkan meluasnya daerah panas dan kering sehingga tingkat kenyamanan akan berkurang menjadi tidak nyaman.

Dalam ruangan publik terbuka perkotaan, khususnya di kota-kota besar yang beriklim tropis, pejalan kaki sering terpapar beban panas yang tinggi, yang dapat menyebabkan ketidaknyamanan termal. Kondisi yang sesuai untuk kenyamanan termal di lingkungan perkotaan dapat diperoleh melalui perawatan yang tepat pada ruangan terbuka, yang dapat mendorong orang untuk berjalan kaki, meningkatkan iklim mikro perkotaan, mengurangi konsumsi energi dan sebagainya, dengan implikasi untuk kota yang lebih (Nikolopoulou dan Steemers, 2004; Nikolopoulou, dkk., 2001). Perkembangan kegiatan masyarakat kota di ruang terbuka saat ini yang semakin dinamis dan mengarah ke peningkatan produktivitas maupun kualitas hidup membutuhkan ruang terbuka yang nyaman dan atraktif. Sehingga, rancangan lingkungan termal yang nyaman dinilai penting karena kenyamanan termal menjadi kriteria utama untuk memutuskan berkegiatan di ruang luar atau untuk memilih ruang luar yang akan digunakan (Hamilton dan Lau, 2005; Lin dkk. 2006; Lin dan Matzarakis, 2008; Binarti dkk., 2018).

Menurut standar ISO (Internasional Standard Organization) 7730, kenyamanan termal merupakan hubungan yang kompleks antara temperatur udara, kelembaban udara, dan kecepatan aliran udara, ditambah lagi dengan jenis pakaian dan aktivitas serta tingkat metabolisme penghuni yang menghadirkan ungkapan perasaan kepuasan terhadap kondisi udara di dalam suatu lingkungan. Kondisi kenyamanan juga dapat didefinisikan sebagai kenetralan termal, yang berarti bahwa seseorang merasa tidak terlalu dingin atau terlalu panas (ISO-7730, 1994). Terdapat enam parameter tingkat kenyamanan termal outdoor; yakni: temperatur udara, kelembaban relatif, temperatur radiasi dan kecepatan angin sebagai elemen lingkungan termal, serta metabolisme tubuh manusia dan insulasi pakaian sebagai faktor fisik dan fisiologis manusia (ASHRAE, 2013; Binarti, dkk., 2018). Berdasarkan definisi tersebut, kajian ini mengukur tingkat kenyamanan termal di luar ruangan dengan menggunakan dua parameter iklim, yaitu temperatur udara dan kelembapan relatif.

Ada beberapa studi yang mengukur tingkat kenyamanan termal di kota-kota besar terutama DKI Jakarta. Wati dan Fatkhuroyan (2017) menganalisis tingkat kenyamanan termal menggunakan indeks THI yang mengasilkan bahwa semakin ke pusat kota semakin besar prosentase ketidaknyamanannya. Lebih lanjut, Wati dan Nasution (2018) menghubungkan indeks panas termis dengan jumlah kendaraan bermotor di megacity DKI Jakarta dan menemukan bahwa peningkatan jumlah kendaraan bermotor yang pesat dapat meningkatkan indeks panas Humidex. Selain DKI Jakarta, penelitian lainnya (Maru, dkk., 2015) mencoba menganalisis tingkat kenyamanan di kota Makassar yang sudah mulai menurun bagi penduduk kota dengan observasi awal terhadap suhu rata-rata yang dilakukan pada siang dan malam hari adalah $31,29^{\circ} \mathrm{C}$ dan $27,4^{\circ} \mathrm{C}$ secara berturut (Maru dan Baharuddin, 2014). Selain itu, Rahim dkk (2016) meneliti tingkat kenyamanan di Makassar dengan melihat karakteristik temperatur yang menghasilkan zona kenyamanan termal tidak dapat dipenuhi pada bulan Juli-Oktober karena suhu dapat mencapai $>33^{\circ} \mathrm{C}$.

Penelitian ini bertujuan untuk menganalisis tingkat kenyamanan dan kecenderungannya berdasarkan indeks THI (Nieuwolt, 1977) yang telah dimodifikasi klasifikasi batas kenyamanannya untuk wilayah tropis oleh Effendy (2007) di beberapa kota besar di Pulau Sulawesi yang belum banyak dikaji sebelumnya. Hal ini akan bermanfaat untuk perencanaan pengembangan tata kota yang hijau dan ramah lingkungan karena dalam iklim perkotaan, perancangan dan arsitektur bangunan kota telah memfokuskan pada kenyamanan manusia/bioklimat (Emmanuel, 1993; 1997; Mertens, 1999; Wati dan Fatkhuroyan, 2017) 


\section{DATA DAN METODE}

\subsection{Data}

Parameter iklim yang digunakan untuk menghitung indeks THI dalam penelitian ini adalah suhu udara rata-rata dan kelembapan udara relatif harian di titik-titik pengamatan kota-kota besar, dimana satu titik mewakili satu Ibukota Provinsi di Pulau Sulawesi, kecuali Provinsi Sulawesi Tenggara dikarenakan data iklim yang kurang panjang. Data tersebut merupakan data runtun waktu dari tahun 1985-2012 (28 tahun) yang telah dapat merepresentasikan sifat klimatologis parameter iklim. Letak geografis dan ketinggian dari masing-masing titik pengamatan dapat dilihat pada Gambar 1.

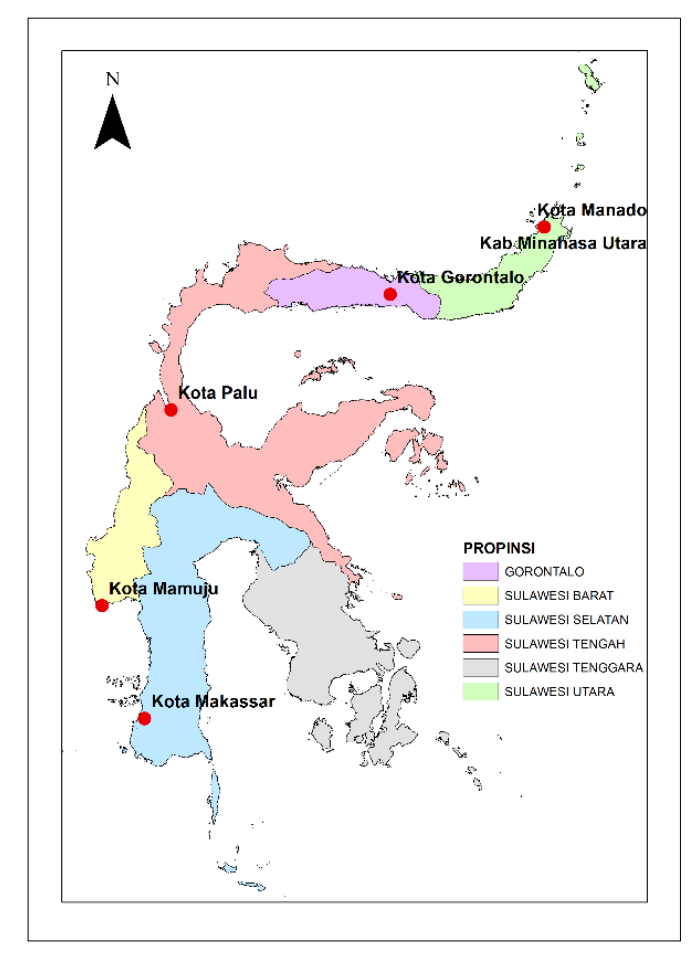

Gambar 1. Peta Lokasi Titik Pengamatan Data Iklim Mewakili Masing-masing Kota

\subsection{Metode}

Metode yang digunakan untuk menghitung tingkat kenyamanan termal di ruangan terbuka menurut formula Nieuwolt (1977) adalah sebagai berikut.

$$
T H I=(0.8 \times T)+\left(\frac{R H \times T}{500}\right)
$$

dengan THI adalah Temperature Humidity Index $\left({ }^{0} \mathrm{C}\right)$, T adalah suhu udara rata-rata $\left({ }^{0} \mathrm{C}\right)$, dan RH adalah kelembapan relatif (\%). Klasifikasi batas kenyamanan untuk iklim tropis adalah $100 \%$ populasi menyatakan nyaman jika nilai THI berada pada rentang nilai $21-24^{\circ} \mathrm{C}$, hanya $50 \%$ populasi merasa nyaman jika THI antara $25-27^{\circ} \mathrm{C}$, serta $100 \%$ populasi tidak merasa nyaman jika nilai $\mathrm{THI}>$ $27^{\circ} \mathrm{C}$. Selain menganalisis tingkat kenyamanan di setiap kota, analisis kecenderungan linier dan koefisien determinasi juga dilakukan untuk melihat seberapa besar peningkatan atau penurunan THI dari tahun ke tahun selama periode 1985 - 2012. 


\section{HASIL DAN PEMBAHASAN}

\subsection{Kondisi Suhu Udara dan Kelembapan Relatif secara Klimatologis di Sulawesi}

Berdasarkan pengamatan suhu udara di beberapa titik pengamatan (Gambar 2), umumnya suhu tertinggi secara klimatologis terjadi pada bulan Agustus untuk Kota Manado $\left(26.8^{\circ} \mathrm{C}\right)$ dan Minahasa Utara $\left(27^{\circ} \mathrm{C}\right)$ sedangkan bulan Oktober untuk Kota Palu (27.8 $\left.{ }^{\circ} \mathrm{C}\right)$, Mamuju (28.3) dan Makassar (27.6) serta untuk Kota Gorontalo $\left(27.3^{\circ} \mathrm{C}\right)$ memiliki 2 puncak suhu tertinggi yaitu pada bulan Mei dan Oktober. Pola suhu bulanan secara klimatologis hampir sama pada semua kota-kota besar di Sulawesi kecuali untuk kabupaten Minahasa Utara yang mengalami sedikit peningkatan suhu udara pada bulan Mei dibandingkan yang lainnya. Secara keseluruhan, suhu udara di Kota Palu dan Mamuju cenderung selalu tinggi setiap bulannya dan tidak pernah mengalami suhu dibawah $27^{\circ} \mathrm{C}$ secara klimatologis.

Kelembapan relatif (RH) klimatologis di Pulau Sulawesi (Gambar 2) selalu berada diatas $65 \%$ yang berarti masih terdapat cukup uap air di udara permukaan. RH tertinggi umumnya terjadi pada musim penghujan (Okt-Mar), yaitu bulan Januari dengan nilai $87.4 \%$ untuk Kota Manado, $89.2 \%$ untuk Minahasa Utara, $83.5 \%$ untuk Gorontalo, dan $87.8 \%$ untuk Makassar. Sedangkan Kota Palu dan Mamuju memiliki RH yang tinggi pada bulan Juni dan Mei secara berturut dengan nilai $77.5 \%$ dan 81.1 $\%$. Pola RH bulanan secara klimatologis menunjukkan pola yang sama dengan pola hujan monsunal pada umumnya, dimana pada musim kemarau (Apr-Sep) kandungan uap air relatif di udara berkurang. Secara keseluruhan, hanya Kota Palu yang memiliki RH dibawah $80 \%$ setiap bulannya sehingga kota Palu cenderung lebih kering dibanding kota lainnya.

Jika melihat hubungan suhu dan RH pada kota-kota di Sulawesi umumnya menujukkan pola yang terbalik, artinya saat suhu tinggi maka RH akan rendah. Dari Gambar 2 dapat dianalisis bahwa grafik suhu dan RH memiliki jarak yang renggang khususnya pada Kota Palu dan Mamuju, artinya kandungan uap air di udara sangat rendah dan suhu udara menunjukkan nilai yang tinggi sepanjang bulan. Sehingga, dapat disimpulkan bahwa Kota Palu dan Mamuju merupakan kota dengan kandungan uap air yang relatif rendah dengan suhu yang relatif tinggi secara klimatologis jika dibandingkan dengan kota lainnya.

\subsection{Tingkat Kenyamanan Termal Klimatologis di Sulawesi}

Analisis tingkat kenyamanan berdasarkan indeks THI di kota-kota Pulau Sulawesi dapat dirangkum dalam bentuk prosentase frekuensi harian kategori Nyaman, Sebagian Nyaman dan Tidak Nyaman (Tabel 1 dan Gambar 3). Tingkat kenyamanan harian umumnya dirasakan nyaman oleh sebagian populasi (50\%) dengan prosentase terbesar di semua kota diatas $68 \%$. Kota Gorontalo dan Palu memiliki prosentase kategori Sebagian Nyaman yang lebih besar dibandingkan kota lainnya, yaitu $79.8 \%$ atau 287 hari/tahun dan $78.5 \%$ atau 291 hari/tahun secara berturut. Sedangkan kota Manado merasakan kategori sebagian nyaman sebesar $66.9 \%$ atau 244 hari/tahun, Minahasa Utara sebesar 242 hari/tahun, Mamuju sebesar $68.2 \%$ atau 249 hari/tahun, dan Makassar sebesar $68.7 \%$ atau 251 hari/tahun. 


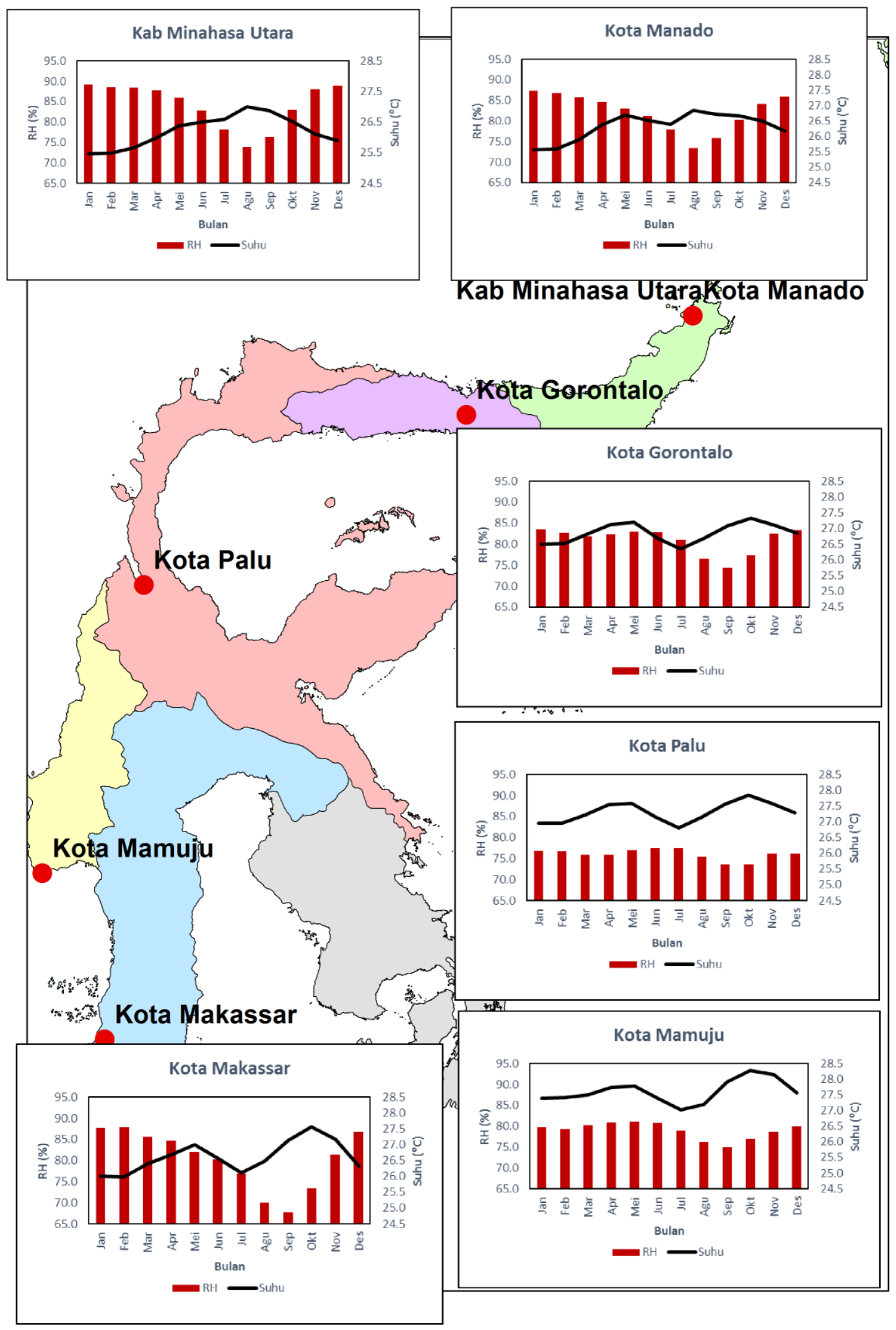

Gambar 2. Suhu udara dan RH klimatologis di Sulawesi

Tabel 1. Prosentase Frekuensi Harian Tingkat Kenyamanan di Sulawesi periode 1985-2012 


\begin{tabular}{|c|c|c|c|c|c|c|c|c|}
\hline \multirow{2}{*}{ THI $\left({ }^{\circ} \mathrm{C}\right)$} & Kategori & $\begin{array}{c}\text { Kota } \\
\text { Manado }\end{array}$ & $\begin{array}{c}\text { Kab } \\
\text { Minahasa } \\
\text { Utara }\end{array}$ & $\begin{array}{c}\text { Kota } \\
\text { Gorontalo }\end{array}$ & Kota Palu & $\begin{array}{c}\text { Kota } \\
\text { Mamuju }\end{array}$ & $\begin{array}{c}\text { Kota } \\
\text { Makassar }\end{array}$ & Rata-rata \\
\hline $21-24$ & Nyaman & 31.6 & 31.9 & 14.8 & 11.2 & 4.8 & 26.2 & 20.1 \\
\hline $25-27$ & Sebagian Nyaman & 66.9 & 66.4 & 79.8 & 78.5 & 68.2 & 68.7 & 71.4 \\
\hline$>27$ & Tidak Nyaman & 1.5 & 1.7 & 5.3 & 10.2 & 24.7 & 5.1 & 8.1 \\
\hline
\end{tabular}

Tingkat kenyamanan dengan kategori Nyaman yang dirasakan oleh seluruh populasi (100\%) memiliki prosentase yang lebih kecil dari kategori Sebagian Nyaman dengan prosentase terbesar dimiliki oleh Minahasa Utara sebesar $31.9 \%$ atau 117 hari/tahun dan Kota Manado sebesar 31.6 atau 115 hari/tahun. Penduduk kota Makassar merasakan nyaman dengan prosentase sebesar $26.2 \%$ atau 96 hari/tahun, kota Gorontalo sebesar $14.8 \%$ atau 54 hari/tahun, kota Palu sebesar $11.2 \%$ atau 41 hari/tahun dan yang terkecil adalah Mamuju sebesar $4.8 \%$ atau 18 hari/tahun. Sedangkan seluruh penduduk kota yang merasakan tidak nyaman paling sering dirasakan oleh Kota Mamuju dengan prosentase sebesar $24.7 \%$ atau 90 hari/tahun, kota Palu sebesar $10.2 \%$ atau 37 hari/tahun, kota Gorontalo sebesar $5.3 \%$ atau 20 hari/tahun, kota Makassar sebesar $5.1 \%$ atau 19 hari/tahun, Minahasa Utara sebesar $1.7 \%$ atau 6 hari/tahun dan Manado $1.5 \%$ atau 6 hari/tahun.

Rata-rata tingkat kenyamanan dengan kategori sebagian nyaman sebesar $71.4 \%$, nyaman sebesar $20.1 \%$ dan tidak nyaman $8.1 \%$ di Pulau Sulawesi. Sehingga, secara umum Kota Manado dan Kab Minahasa Utara merupakan kota yang paling nyaman dirasakan oleh populasi kota karena paling jarang terpapar suhu dan RH yang tidak nyaman. Kekurangan dari penelitian ini adalah masih adanya data pengamatan iklim yang kosong akibat tidak adanya pengamatan pada hari tersebut kecuali untuk kota Palu yang tidak memiliki data kosong selama periode 1985-2012. Namun, untuk analisis klimatologis data kosong yang terbilang sedikit tidak berpegaruh besar pada hasil penelitian (Gambar 3).

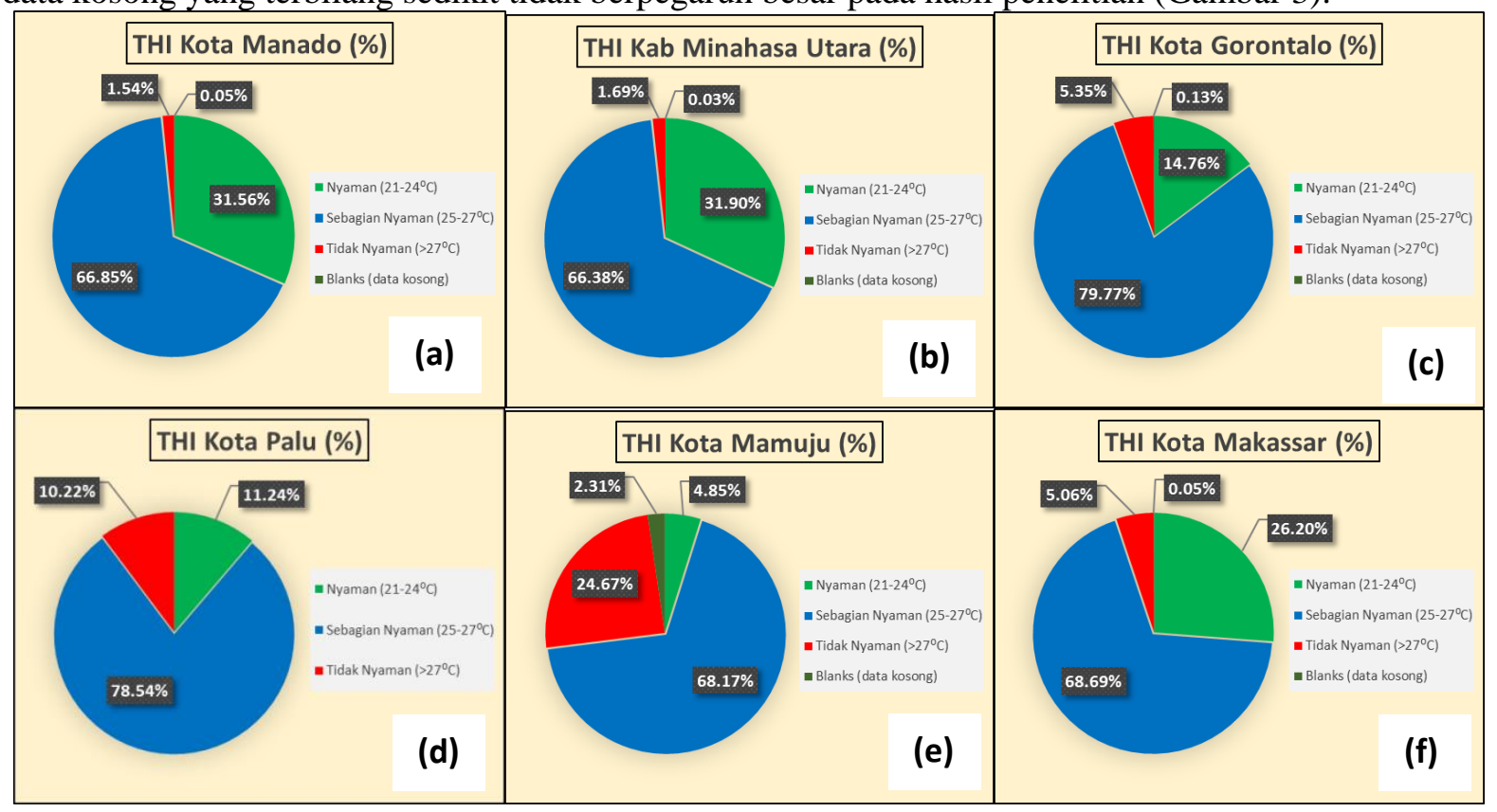

Gambar 3. Diagram tingkat kenyamanan di Sulawesi

THI bulanan secara klimatologis pada Gambar 4 menunjukkan pola yang bimodal dengan puncak terjadi pada bulan Mei dan Oktober dan THI terendah terjadi pada bulan Juli dan Agustus. Hal ini sesuai dengan pola yang ditunjukkan oleh suhu udara di masing-masing kota. Kota Mamuju memiliki nilai THI bulanan yang tertinggi dibandingkan kota lainnya dengan rata-rata berkisar $26.4^{\circ} \mathrm{C}$ dan terendah terjadi di kabupaten Minahasa Utara dengan rata-rata berkisar $25.4^{\circ} \mathrm{C}$. Hal ini sejalan dengan sifat klimatologis dari suhu udara dan kelembapan relatif di kedua kota tersebut. 


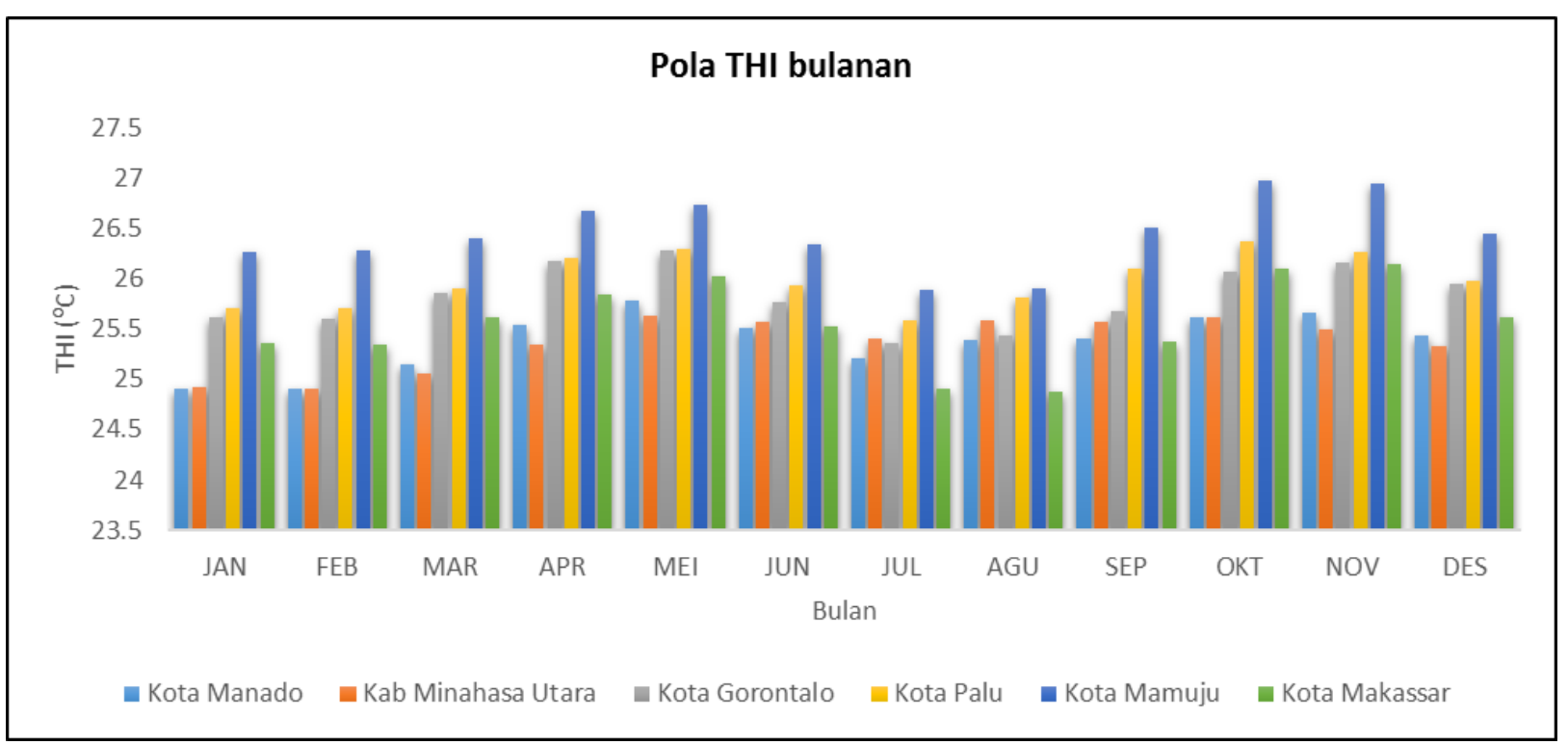

Gambar 4. Pola THI Bulanan di Sulawesi

Berdasarkan Gambar 5a - 5e, nilai THI tahunan cenderung meningkat dari tahun ke tahun selama periode 1985-2012 hampir disemua kota di Sulawesi kecuali kota Mamuju yang menunjukkan penurunan nilai THI. Peningkatan nilai THI terbesar setiap tahunnya terjadi di kota Makassar sebesar $0.03^{\circ} \mathrm{C} /$ tahun atau $0.3^{\circ} \mathrm{C} / 10$ tahun dan diikuti oleh kota Palu sebesar $0.027^{\circ} \mathrm{C} /$ tahun atau $0.27^{\circ} \mathrm{C} / 10$ tahun. Selanjutnya, nilai THI meningkat sebesar $0.02^{\circ} \mathrm{C} /$ tahun atau $0.2^{\circ} \mathrm{C} / 10$ tahun terjadi di kota Manado, Minahasa Utara dan Gorontalo. Sedangkan THI cenderung menurun di kota Mamuju dengan nilai yang kecil yaitu berkisar $0.003^{\circ} \mathrm{C} /$ tahun atau $0.03^{\circ} \mathrm{C} / 10$ tahun. Namun, peningkatan dan penurunan tersebut tidak terjadi secara signifikan dengan koefisien determinasi (R2>50\%) yang artinya data yang mewakili lebih dari $50 \%$ kecuali pada kota Manado dan Minahasa Utara. Nilai koefisien determinasi kota Gorontalo, Palu dan Makassar berkisar $40 \%$ sedangkan hanya $2 \%$ untuk kota Mamuju.

Terjadinya kecenderungan peningkatan nilai THI dapat disebabkan oleh laju pertumbuhan penduduk di perkotaan yang merupakan fenomena alamiah untuk meningkatkan kesejahteraan ekonomi masyarakat. Laju pertumbuhan penduduk perkotaan di Indonesia pada dua dasawarsa terakhir menunjukkan peningkatan yang sangat pesat. Pertumbuhan penduduk perkotaan pada periode 19711980 mencapai 4,60 persen per tahun, yang kemudian meningkat menjadi 5,36 persen per tahun pada perode 1980-1990. Laju pertumbuhan penduduk perkotaan pada periode 1980-1990 adalah dua setengah kali lebih besar daripada laju pertumbuhan penduduk secara keseluruhan, yang besarnya hanya 1,97 persen per tahun. UN melaporkan bahwa pertambahan penduduk perkotaan di Indonesia sekitar 65 persen disebabkan oleh migrasi dan reklasifikasi. Dan sisanya hanya 35 persen disebabkan oleh pertumbuhan alamiah penduduk kota itu sendiri (Adam, 2010). Fenomena suhu yang sangat tinggi ketika tengah hari bersifat menyeluruh di seluruh permukaan bumi yang utamanya berada di sekitar khatulistiwa. Pada kawasan perkotaan cenderung lebih tinggi dibandingan sub urban. Hal ini dikarenakan adanya geliat aktifitas kota dan beberapa sumber panas yang dapat memicu peningkatan suhu udara kota seperti mobilitas kendaraan, aktifitas industri, rumah tangga dan berbagai aktifitas yang melibatkan pembakaran bahan fosil (Tjasyono, 2004). 


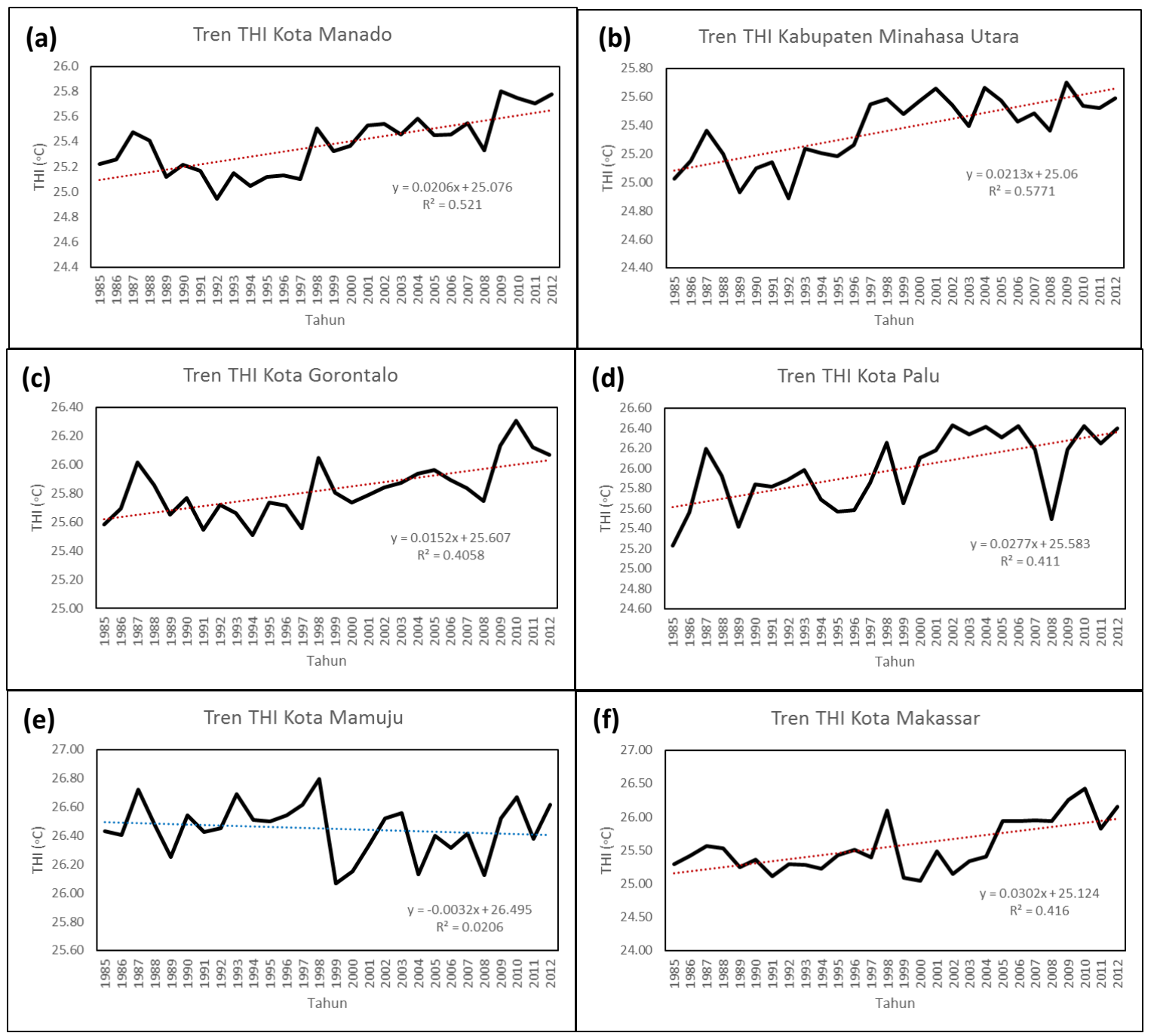

Gambar 5. Tren THI di Sulawesi Periode 1985-2012

Selain tingkat urbanisasi, sifat-sifat fisis permukaan akan berubah akibat perubahan penutupan lahan seperti albedo, emisivitas, dan kekasapan permukaan yang berakibat mengubah panas yang diterima oleh permukaan tersebut. Sehingga, konversi lahan bervegetasi dan badan air menjadi daerah pemukiman akan menyebabkan semakin meluasnya daerah panas dan kering. Jika kondisi ini terus berlanjut, maka tingkat kenyamanan akan berkurang menjadi tidak nyaman (Kalfuadi, 2009; Wati dan Fatkhuroyan, 2017). Ketersediaan Ruang Terbuka Hijau yang luas dapat menyerap karbondioksida dan akan berpengaruh positif terhadap kesejukan diperkotaan (Anshori, 2008). Berdasarkan penelitian Asiani (2007) dalam Wati dan Fatkhuroyan (2017) , RTH dapat menurunkan suhu udara sekitar 5,68\% dan meningkatkan kelembapan udara sekitar $4 \%$.

\section{KESIMPULAN}

Secara klimatologis, rata-rata prosentase tingkat kenyamanan termal harian menggunakan indeks THI di Sulawesi umumnya hanya sebagian populasi (50\%) perkotaan merasakan nyaman atau pada kategori Sebagian Nyaman dengan rata-rata sebesar $71.4 \%$ atau 261 hari/tahun. Kategori Nyaman ratarata terjadi sebesar $20.1 \%$ atau 73 hari/tahun dan kategori Tidak Nyaman terjadi sebesar $8.1 \%$ atau 30 hari/tahun. Tingkat kenyamanan yang paling rendah dirasakan oleh penduduk Kota Mamuju sedangkan perasaan nyaman di ruangan terbuka dirasakan oleh penduduk kota Manado dan Minahasa Utara. Kecenderungan peningkatan indeks THI terjadi hampir disemua kota kecuali Mamuju dengan laju terbesar dialami oleh kota Makassar. Taraf signifikansi > $50 \%$ terjadi di Kota Manado dan Minahasa Utara sehingga tingkat kenyamanan dari tahun ke tahun semakin tidak nyaman di kedua kota tersebut. Namun, laju peningkatannya tidak sebesar kota Makassar. Tren peningkatan nilai THI di Sulawesi 
disebabkan oleh tingkat urbanisasi yang semakin pesat dan perubahan penggunaan lahan vegetasi menjadi non vegetasi yang terbangun sehingga menyebabkan berkurangnya RTH

\section{DAFTAR PUSTAKA}

Adam, F.P. (2010). Tren Urbanisasi di Indonesia. https://www.researchgate.net/publication/319718757. Universitas Pattimura. Ambon.

Anshory, Nasrudin. 2008. Kearifan Lingkungan Dalam Perspektif Budaya Jawa. Penerbit yayasan obor. Jakarta.

ASHRAE (2013): ANSI/ASHRAE Standard 55-- Thermal Environmental Conditions forHuman Occupancy. Atlanta: American Society of Heating, Refrigerating and Air-Conditioning Engineers (ASHRAE) Inc.

Asiani Y. (2007). Pengaruh kondisi ruang terbuka hijau (RTH) pada iklim mikro di Kota Bogor Tesis. Depok (ID): Universitas Indonesia.

Binarti, F., Kusuma H.E., Wonorahardjo, S., \& Triyadi, S. (2018). Peranan Unsur-Unsur Ruang Terbuka pada Tingkat Kenyamanan Termal Outdoor: Antara Persepsi dan Pengetahuan. Jurnal Arsitektur KOMPOSISI, Volume 12, Nomor 1, April 2018.

Effendy, S. (2007). Keterkaitan Ruang Terbuka Hijau dengan Urban Heat Island Wilayah Jabodetabek. Disertasi. Sekolah Pascasarjana IPB, Bogor.

Emmanuel, R. (1993). A hypothetical 'shadow umbrella'for thermal comfort enhancement in the Equatorial urban outdoors. Architectural Science Review, 36(4), 173-184.

Emmanuel, R., (1997). Summertime heat island effects of urban design parameters, Ph.D. Dissertation, University of Michigan, U.S.A.

Hamilton, J. M. \& Lau, M. A. (2005). The role ofclimate information in tourist destinationchoice decision-making. Proceedings of the17th International Congress of Biometeorology (ICB 2005), Garmisch-Partenkirchen,Germany, 9-5 September 2005. Offenbacham Main: Deutscher Wetterdienst.

ISO-7730. (1994). Moderate Thermal EnvironmentsDetermination of The PMV and PPD Indices and Specification of The Conditions for Thermal Comfort. Switzeland: International Organization for Standardization.

Kalfuadi, Y. (2009). Analisis temperature heat index (THI) dalam hubungannya dengan ruang terbuka hijau (Studi Kasus : Kabupaten Bungo - Propinsi Jambi). Skripsi. FMIPA. IPB, Bogor.

Lin, T. P., Hwang, C. C. \& Cheng, H. Y. (2006). The influence of climate information on travel arrangements. Proceedings of the 8th Leisure, Recreation and Tourism Research Symposium, Taipei, 7 Oktober 2006. Outdoor Recreation Association, Taipei, 120-126.

Maru, R., \& Ahmad, S. (2014). Daytime temperature trend analysis in the city of Jakarta, Indonesia. World Applied Sci. J, 32, 1808-1813.

Maru, R. \& Baharuddin, I. I. (2014).Urban Heat Island Intensity (UHII) Kota Makassar Sulawesi Selatan.Laporan penelitian.Tidak dipublikasikan.

Maru, R., Baharuddin, I.I., Zhiddiq, S., Arfan, A., \& Bayudin. (2015). Trend Analysis of Urban Heat Island Phenomenon in the City of Makassar, South Sulawesi, Indonesia using Landsat. Asian Journal of Applied Sciences (ISSN: 2321 - 0893) Volume 03 - Issue 05, October 2015. www.ajouronline.com.

Mertens, E., (1999). "Bioclimate and city planning - open space planning," Atmospheric Environment, 33(24-25): 4115-4123.

Nieuwolt S. (1977).Tropical climatology. London: Wiley; 
Nikolopoulou M., Baker N., \& Steemers K. (2001). Thermal comfort in outdoor urban spaces: understanding the human parameter, Sol. Energy 70 (2001) 227e235.

Nikolopoulou M. (2004). Outdoor comfort. in: M.A. Steane \& K. Steemers (Eds.). Environmental Diversity in Architecture. Spon Press. London. New York.

Rahim, R., Asniawaty, Triyatni, M., Amin, S. \& Hiromi, R. (2016). Karakteristik Data Temperatur Udara dan Kenyamanan Termal di Makassar. TEMU ILMIAH IPLBI 2016.

Rushayati, S. B., \& Hermawan, R. (2013). Karakteristik kondisi urban heat island DKI Jakarta. Media konservasi, 18(2).

Tjasyono, Bayong. (2004). Klimatologi. Bandung: ITB

Tursilowati, L. (2005). Fenomena "pulau panas" perkotaan. Last Updated: 2005-12-21 12:35:41. Lembaga Penerbangan dan Antariksa Nasional-LAPAN. Bandung-Indonesia.

Wati, T. \& Fatkhuroyan. (2017). Analisis Tingkat Kenyamanan Di DKI Jakarta Berdasarkan Indeks THI (Temperature Humidity Index). Jurnal Ilmu Lingkungan Vol. 15 Issue 1 (2017): 57-63. Program Studi Ilmu Lingkungan Sekolah Pascasarjana UNDIP. Semarang.

Wati, T. \& Nasution, R.I. (2018). Analisis Kenyamanan Termis Klimatologis di Wilayah DKI Jakarta dengan Menggunakan Indeks Panas (Humidex). Widyariset Vol. 4 No. 1 (2018) Hlm. 89 102. DOI: http://dx.doi.org/10.14203/widyariset.4.1.2018.89-102. 